\title{
The Defence of French: A Language in Crisis?
}

Robin Adamson. Clevedon, UK: Multilingual Matters. 2007. Pp. xx + 199.

As Robin Adamson explains in The Defence of French: A Language in Crisis?, due to the long history of centralized power and of governmental control of language, the French have a singular relationship with their mother tongue. It is not surprising then that France's defense of its language is uniquely passionate and uniquely polemical. By referencing past works on the subject, and through her own analysis of the history and current state of the defense of the French language, the author evaluates the situation, draws her own conclusions as to whether or not the language is endangered, and makes a prognosis about its future. Assisting the reader through this rather dense work is a list of the abbreviations of the 34 organizations and political bodies referenced throughout the work as well as frequent tables that depict timelines and break down the information into bite-sized pieces.

The book is divided into six chapters. The introduction enumerates a number of tensions surrounding the defense of French, including a generational divide, the growing disparity between the spoken and the written language, and a government caught between the opposing polls of dirigisme - the wish to maintain the classical concentration of power-and liberté - the need to respond to mounting calls for political decentralization. She also presents evidence that supports the position of both staunch defenders of the language, les résistants, and those who maintain that French is alive and well. However, Adamson shows that this story is not one of les résistants versus libertarians; oppositions exist within the résistant camp, which is divided between private groups and individuals with emotional motivations, and the influential governmental agencies with political aims. In this section, Adamson also reveals her objective of arguing that the key to the survival of French lies in the country's favorable reception of plurilingualism rather than the defensive measures of language protection that have been favored by the French government.

The first chapter, "Defending French: A Story of Love and Power," provides a detailed chronological account of the history of the defense of French dating back to the 16th century. Adamson highlights approximately 20 events - ranging from the Ordonnance de Villers-Cotterêts in 1539 to the most recent Sommet de la Francophonie in 2006 - and a handful of key players, including François Ier, du Bellay, Malherbe, Richelieu, The Abbé Grégoire, Jules Ferry, and François Mitterrand. The author stresses the fact that, as early as the 16th century, France witnessed a linking of political centralization and a linguistic policy that supported standard French. Over the centuries, this bond between language and power and the ensuing prideful love of French has resulted in the codification of the language, the standardization of education, and a missionary-like policy of propagating the French language across the globe. However, as Adamson is quick to point out, along with the advancement of standard French came efforts to obliterate all other versions of the language. A prime example is la langue d'oc, the Italianized French fashionable in the 16th century, and numerous other dialects and patois. In the final two sections of the chapter, the author touches on the effect of the proliferation of English technological terms on French, as well as the legal measures taken by the French government and by private individuals and organizations in an attempt to protect the language. She also emphasizes the problems resulting from the inordinate number of groups working in the defense of French: confusion, redundancy, and loss of focus. 
In the following chapter, "The Dynamics of Defence: Some Contemporary Themes and Trends," Adamson examines the ways in which the defense of French has been modified according to various political and social influences on the language. The trends explored include Frenchspeaking professionals who work in a mainly English-speaking context, the apparent threat of English domination, regional and minority languages, France and the European Union, and the Internet as a resource for the defense of French. The author goes into detail about the protective laws created by the French government in the second half of the 20th century, discusses the domestic and international response to these legal measures, and rates their effectiveness. Adamson then reviews the history of the regional and minority languages in France and identifies 1980 as the first time these languages were granted any rights. Though these privileges remain limited, there has been some official celebration of these languages in the last two decades. Skeptical, the author questions this recent change in policy. She wonders if France's move to protect linguistic minorities within its borders is, in fact, motivated by a desire to protect itself and to garner support from its allies against what it perceives as the onslaught of English. In the following section, Adamson considers several key moments in the history of the European Union related to language use and policy and suggests that, due to the fact that the newly admitted member countries use English as a lingua franca, France's fear of an English-only Union may become a reality in the near future. In the final section of the chapter, the author briefly discusses the various web sites - both governmental and those designed by private organizations - used in the defense of language. Though Adamson agrees that the Internet has great potential for use in this area, she maintains that the pitfalls of the web (i.e., the need for constant maintenance), lead to the same problems of disorder and dispersion discussed in Chapter 1.

Chapter 3, "Official Agencies: The Language of Power," explores the four most prestigious governmental agencies dedicated to the defense and propagation of French: the Académie Française, the Alliance Française, the Délégation Générale à la Langue Française et aux Langues de France, and the Organisation International de la Francophonie (OIF). Adamson discusses the agencies' histories, explains their current missions, and points to the French tendency to conceive of the problem of language protection as a job fit only for a government agency. She also investigates the tensions between various agencies. For example, in contrast to the largely selfprotective position taken by the Académie Française, the Alliance Française works to foster relationships with existing groups of French speakers around the globe. Referring to the previous chapter, Adamson also draws attention to the official shift from the undervaluing of regional and minority languages to a policy that regards support for local languages as vital. Also of note is the author's discussion of recent controversial admissions to the OIF of oppressive regimes, namely Haiti, Congo, Côte d'Ivoire, as well as other countries such as Albania, Bulgaria, and Macedonia where French is not spoken. What may at first glance seem like puzzling decisions by the OIF become less so when Adamson reveals the linguistic incentives in the admission of these states: French will be taught in these countries' schools. Finally, the author makes a connection between the confusion that ensues from the overwhelming number of private organizations and agencies that work to protect French within the country, and the French people's uncertainty as to the function of the OIF, due to the high number of agencies working to support la Francophonie.

The fourth chapter, "Language and Politics: Inseparable Partners," focuses on three different time periods in the history of France when language and politics have intersected in crucial ways. The historical moments and themes discussed are clear from the subtitles of the 
chapter, "Kings and language: the 16th and 17th centuries," "Revolution and language: the 18th century - Revolution, the convention, and the official language," and "Republic, empire and la Francophonie: the foreign and colonial policy of France, taking French to the wider world." Here, Adamson expands the theme of governmental control of language and considers the specific cases of the political language movements in Alsace, Brittany, Corsica, Occitania, and Savoy. She also develops the discussion of the OIF begun in the previous chapter. Of particular interest is the criticism aimed at the OIF from both inside and outside France. While some citizens of former colonies characterize France's support of the OIF as motivated by neo-colonial intentions, French citizens who hope that la Francophonie will compete with both the British Commonwealth and the United States feel that their country has not devoted enough resources to the OIF.

In the fifth chapter, "Languages in Europe: How Does France Compare?", Adamson compares France's language policies with those of four of its neighbors: Germany, Italy, Spain, and the United Kingdom. Interestingly, the author uses the web site of the US English Foundation for her data regarding official languages throughout the world. As Adamson points out, English speakers have historically had enough confidence in the prevalence of their tongue that they have not had to consider defending it. Recently, however, the growing number of Spanish speakers in the U.S. has led some English-speaking Americans to seek protective actions. These data reveal that while the purpose of the linguistic legal provisions in France is almost exclusively to defend French, the linguistic provisions of the constitution in France are intended to protect the minority languages. On the other end of the spectrum in Great Britain, English is not mentioned in any law, but three of the six minority languages are protected legally. Though the four other countries discussed in the chapter have all made some efforts to guard their majority language, the overarching theme is that France is uniquely fervent in its defense of its language.

The final chapter, "Problems and Paradoxes: Interference and Interaction," discusses the relationship between language and identity. Adamson begins the chapter by contrasting the positions held by linguists and non-linguists regarding the defense of French. As she explains, since most non-linguists equate language with words, they are more apt to want to protect their language from invading foreign words, a practice that the author deems highly ineffective. Linguists, on the other hand, understand that language is richer than a mere collection of words and they know that change in the vocabulary of a language is inevitable and natural. Adamson highlights several other interesting conflicts between non-linguists and linguists and between résistants and those who oppose them. First, the author discusses some defenders of French who, recalling the attitudes of the 18th century, believe that French must be protected because, due to its unique "universal humanising, civilising mission" (p. 145) the language is fated to have a leading role on the world's stage. Linguists respond to this position by maintaining that political and economic factors regulate the influence of a given language rather than any fundamental characteristics of the language. Another disagreement explored is between those defenders of French who are concerned about English domination, and those that dismiss this anxiety as naïve. The former fear that, along with the ascendancy of the language, Anglo-Saxons will also impose their way of life. Adamson, who falls into the latter category, posits that when discussing speakers of a particular language, "it is surely simplistic to assume that their thought patterns are inevitably identical in all respects" (p. 146). Finally, the author points out that some of the versions of French omitted from 21st century standard French include those spoken in the cités, and those used in the media, in music, on the Internet, and in text messaging. The French that some defenders are trying 
to save, therefore, is not a reality but an ideal, and this ideal does not unite all French citizens; rather, it pushes away many youths and minorities. Those holding the opposite point of view admire the inventiveness and liveliness of contemporary French. In the final part of the chapter, Adamson explores the close link between language and identity. Though many equate the two and thus consider "a language crisis... [to be] an identity crisis" (p. 153), the author argues that there are other, more important facets of the French identity that need to be cultivated.

Adamson poses three important questions in the conclusion: (a) Is the French language truly in crisis?, (b) Should the language be defended and is this possible?, and (c) If yes, how should the language be defended? To the first question, Adamson responds that although French does not face any imminent danger, English is a true threat to the language. The author leaves the second question up to the French, saying, "if the French believe their language is in crisis and is worth defending, and if they are prepared to go to such lengths to do so, it is necessary to accept that the effort is an existential necessity for them" (p. 169). Adamson's response to the third question is forward-looking. She believes that the French need to embrace the diversity of their evolving language that is at long last liberating itself from the "bonds of the powerful élites and becoming a democratic channel of communication for the whole francophone community" (p. 174). Provided the French continue to give a French flavor to the words they borrow from other languages and respond creatively to the diverse linguistic influences around them, the French language will prosper.

Though the subject covered in the book is not novel, Adamson provides a critical outsider's perspective on the matter. The author does make it clear that the issue has been addressed in numerous books on the history of French, as well as in works dealing solely with the defense of French. While validating the distress felt by speakers of French regarding the future of their language, the author recognizes the inevitability of language evolution. The important social and historical context provided by Adamson allows the reader to both empathize with the defenders of French and maintain a positive outlook as to the language's destiny. Adamson's work is quite relevant in the 21 st century because she deals with the changing face of France and makes occasional reference to the racial and religious tensions in the country. This book will appeal to linguists and non-linguists alike, as well as to Francophiles and students of European and postcolonial history. Adamson's work will be of particular interest to an Anglophone audience because she explores our privileged position with regard to our language and uses it as a point of comparison for her inquiry. Finally, French citizens who represent minority languages and cultures may take heart after reading Adamson's democratic and optimistic message.

\section{RACHEL NISSELSON}

Vanderbilt University 